\title{
Importance of Monitoring Mass Tourism for Sustainable Development in Bangladesh
}

\author{
Jashim Uddin Sarker \\ Lecturer, Dept. of Tourism \& Hospitality Management, The People's University of Bangladesh, Dhaka, BANGLADESH \\ *E-mail for correspondence: jashimxp@gmail.com
}

\begin{abstract}
Tourism is a buzzword worldwide at present days. Bangladesh is also a beneficial country like many others in the world since this country is full of potentials with natural resources and tourism industry. Tourism often seems a blessing for the nation. However, mass tourism has both useful and harmful impacts on a country like Bangladesh. Sometimes the rate of negative consequences is higher than the positive ones. Mass tourism brings dangerous results to the local economy, community, culture and environment of a country. However, these dangers can be lessened through proper monitoring, investigation and appropriate interventions of the government as well as other private agencies. This paper explores both the good and bad effects of mass tourism. It also analyzes the significance of effectively monitoring mass tourism so that benefits outweigh the risks.
\end{abstract}

Keywords: Mass Tourism, Monitoring, Impacts, Economy, Society, Culture, Environment, Community, Sustainable Development, Sustainable Tourism

\section{INTRODUCTION}

Is Mass Tourism a curse or blessing to Bangladesh? Indeed mass tourism benefits individuals and some particular agencies; however, it hampers the environment, culture, local economy as well as overall economy of a country. Bangladesh is not an exception to this worldwide phenomenon. This paper presents both the positive and negative impacts of mass tourism on social, economic and environmental aspects of the country. It also analyzes the importance of monitoring potential mass tourism in the country. Besides, the essay discusses how proper monitoring and investigation on mass tourism can help mitigate the adverse results as well as enhance sustainable development in the country.

\section{BACKGROUND}

Bangladesh is an amazing gift of nature, "bestowed with beautiful coasts and beaches, archeological sites, historical and religious places, hills and islands, forests and jungles and attractive countryside" along with abundant water bodies and green fields of agriculture (Rahman, pp. 65-75). Moreover, the varieties of indigenous community with rich cultures make the country even more attractive to both national and international tourists. Bangladesh is a land of natural beauty, historical views, and diversified cultures. Historians affirm that this country has always attracted a huge number of priests, traders, and wanderers from many parts of the world (Howlader). An international travel guide, Lonely Planet put Bangladesh in its list of ten most valued tourist destinations. Its natural beauty, ancient relics, and indomitable hospitality make it a remarkable tourist destination. "Bangladesh witnessed an average growth in the number of tourists by 15 percent in 2006-2010" (Howlader). Central bank data reported that 303, 386 foreigners visited with earnings worth Tk 5562.94 million and a growth of 5.04 percent (Ibid). The size of domestic tourism is also increasing, reaching about 5 million. In 2012 around 1.5 million tourists visited Cox's Bazar, among them 5 percent was foreigners (Ibid). "According to the World Travel and Tourism Council (WTTC), the direct contribution of Bangladesh travel and tourism to its economy in 2011 was Tk 182.5 billion (2.2 percent of total GDP), and is forecasted to rise by 7.3 percent in 2012" (Ibid). Also, "it is expected to rise by 6.1 percent a year till 2022 to Tk 353.7 billion (in constant 2011 prices)" (Howlader). The total contribution of travel and tourism to the country's economy was Tk 381.6 billion (4.7 percent of GDP) in 2011 and was forecasted to rise by 7.6 percent in 2012 (Ibid).

\section{BRIEF CONCEPT OF TOURISM}

Tourism refers to "The commercial organization and operation of holidays and visits to places of interest" (Oxford Dictionaries). "Tourism is a social, cultural and economic phenomenon which entails the movement of people to countries or places outside their usual 
environment for personal or business/professional purposes" (UNWTO). Thus, tourism has implications on the economy, nature, environment and local people of the destination as well as on the tourists themselves. There are three basic forms of tourism such as Inbound, Internal, and International tourism.

Inbound tourism refers to "the activities of a nonresident visitor within the country of reference on an inbound tourism trip" and Internal tourism is "the activities of resident and non-resident visitors within the country of reference as part of domestic or international tourism trips" (UNWTO). On the other hand, International tourism is "the activities of resident visitors outside the county of reference" (Ibid). People travel for different purposes such as recreation, business, religious, cultural, sports as well as to attend workshops, seminars, and conferences (Rahman, pp. 65-75). Therefore, the tourism industry has to meet the needs of all categories of tourists depending on the nature of market demand.

\section{LITERATURE REVIEW}

This research has conducted some studies on evaluating mass tourism. However, they were based on other countries such as USA, Maldives Island, and Mt. Kilimanjaro (Sustainable Travel International). One study was done by Robin Biddulph on "Limits to Mass Tourism's Effects in Rural Peripheries" of three villages in Cambodia (Biddulph, 2015). Another research reported on the impacts of mass tourism on the environment and the local economy in Goa, on coral reefs in Jamaica and effects on culture and society in Malaysia (Responsible Travel, 2015). Additionally, one study was done based on the "Impact of Mass Tourism on The Host Destinations", which was about Spain and some Mediterranean destinations, such as Yugoslavia, Tunisia and Greece (Johnpaul, 2015). Yet, No research has been done regarding the perspective of Bangladesh. On the other hand, there is a high chance of mass tourism in Bangladesh too like other countries. Thus, it is crucial to evaluate the results of this form of tourism and take necessary actions for further improvement of the industry. Considering the fact, this paper analyzes the impacts of mass tourism in Bangladesh, and how beneficiaries can minimize the problem.

\section{Methodology and Objectives of the Study}

This research has been conducted mainly based on secondary data. The materials that have been considered are academic paper, journals, newspapers, websites of Bangladesh Parjatan Corporation (BPC), WTTC, United Nations World Tourism Organization (UNWTO), United Nations Educational, Scientific and Cultural Organization (UNESCO), United Nations Environment Program (UNEP) and other academic sources. The objectives of the study are:

- To explore positive and negative impacts of mass tourism
- To analyze importance of efficiently monitoring potential mass tourism in Bangladesh

- $\quad$ To provide recommendations on how to make mass tourism more efficient for sustainable development of the country

\section{MASS TOURISM}

Mass tourism is the most preferred form of tourism, which "involves tens of thousands of people going to the same resort often at the same time of year" (Gamesby). It is often the cheapest way to holiday. The agencies sell it as a Package Deal. A package deal is the one in which a company provides all of the tourists' needs such as travel or flights, activities, accommodation, and food. These types of offer sometimes make tourism industry unsustainable as well as harm the environment and local culture. Mass Tourism is mostly beneficial for the local people since it generates huge income for them. However, it creates harmful consequences to the environment, culture, and host community; thus, it makes the sector unsustainable.

\section{Potentials of Mass Tourism in Bangladesh}

Bangladesh is one of the most diverse countries in Asia having much potential for tourism development. Tourism industry possesses immense potentials; thus, it has recently emerged as a force having an economic, social and cultural impact across the country. Bangladesh is complete with a bounty of nature. Its immense natural beauties attracted many travelers from far and wide through ages. It's also a place of rich cultural heritage. "Bangladesh is a combination of verdant forests, riverine countryside, and long stretches of sun-bathed beaches, fearsome wilds, meandering rivers and venerable shrines" (Howlader). In thousands years of its history, many renowned kings and Sultan of Bangladesh have ruled the country and left many magnificent cities and monuments which are still significantly visible throughout the country (Howlader). The mighty Bay of Bengal stands in green with all the glory of its past and the splendid colors of its natural gift. Besides, the country constitutes the largest deltaic formation of the world since three of the great rivers the Padma, the Meghna, and the Jamuna flow through the landmass and reach the Bay of Bengal; thus, making the area ideal for both eco-tourism and riverine tourism. Bangladesh is a land of many wonders with a rich history, diversified culture and astonishing natural beauty, making it one of the most marvelous choices for national and international tourists again and again. This land is always prepared to welcome travelers in this land of green and ancient civilization. Indeed, there are all necessary facilities available along with the hospitality of the people to make the travel across Bangladesh a memorable one. 
Additionally, private enterprises are building hotels, motels, and restaurants and benefiting local communities with jobs. Many local youths are working as tourist guides around all the tourist destinations in the country. The government is trying to prioritize locals in selling handicrafts, poultry, meat, fish and vegetables (Howlader). According to WTTC, travel and tourism directly supported 1,329,000 jobs (1.9 percent of total employment) in 2011 (Howlader). It was expected "to rise by 3.6 percent in 2012 and 2.9 percent a year to create $1,840,000$ jobs ( 2 percent of total employment) in $2022^{\prime \prime}$ (Ibid). "In the same year, total contribution of travel and tourism to employment, including jobs indirectly supported by the industry, was 4.1 percent of total employment $(2,880,500$ jobs)" (Ibid). It is expected to rise by 3.9 percent in 2012 to $2,991,500$ jobs and 3.2 percent a year to $4,082,000$ jobs in 2022 (4.5 percent of total)" (Ibid).

Also, the Bangladesh government framed a Tourism Policy in 2010, in order to capitalize on the potential of tourism, which underlines the development of several tourisms such as eco, community, rural, pilgrimage, riverine, archaeological and other types of tourism (Howlader). The policy also emphasized tourism led by the private sector. To enhance marketing and publicity a tourism board has been formed. To fascinate foreign investment and sustainable development of the area, a law titled "Exclusive Tourist Zone and Tourism Protected Area" has been enacted recently. The increase in the facilities is attracting tourists more than before. Also, the rate of tourism highly rises during national holidays such as Eid-Ul-Fitr, Eid-Ul-Adha, Pohela Boishakh, Christmas Day, International Mother Language Day, Victory Day, Independence Day, Durga Puja and other festivals. Additionally, people travel during winter seasons more than other times. Thus, mass tourism occurs frequently in Bangladesh since the weather is comfortable.

\section{POSITIVE IMPACTS OF MASS TOURISM}

This is noticeable that tourism has the most vital effect on the economies of destinations areas. It is because the development of tourist facilities and recreational opportunities has been considered as a positive input to the national balance of payments (Johnpaul. E). Additionally, tourism seems to be economically more efficient than other industries in generating employment and income (Ibid). Mass tourism opens opportunities of jobs in many areas such as in the initial construction of the resorts, in travel, food provision and other service related industries (Games). Local people benefit from income-generating activities. Community people also benefit from infrastructure developments like roads, railways, electricity services and other necessary facilities to accommodate the tourists (Games). Transport adequacy is promoted at the time of mass tourism (Ibid). The earnings from local tax increase; therefore, the local government can invest in schools, healthcare and social services (Ibid). International tourists create a flow of foreign currency that contributes directly to the balance of payments (Johnpaul.E). This flow contributes to the economy of the destination country by creating business turnover, household income, employment and government profits. Also, domestic tourism has an economic effect on the host regions. International tourism brings a flow of foreign currency whereas domestic tourism redistributes national currency inside the country. Furthermore, tourists exchange cultural values with the local people, which develop cultural understanding (Games).

\section{Negative Impacts OF MASS TOURISM}

In spite of having some positive outcomes, there are many hidden costs to tourism, which might have unfavorable economic and environmental effects on the host community (UNEP). Mostly rich countries are better able to profit from tourism than poor countries. Though the least developed countries are in the most urgent need for income, job and rise of the standard of living by means of tourism, they are least able to receive these benefits (UNEP). One of the major negative impacts of mass tourism is over dependence of tourist destinations on this area. This is risky because tourism is unstable and highly susceptible to changes in many factors such as price, changing fashions, global economic trends, and political situations of the host countries (Johnpaul.E). Sometimes the destinations adapt all their resources to tourism without considering that the above factors may lessen the chance of the business (Ibid). Thus, they create vulnerabilities to themselves because the political situation in a country, the economy, a war or the terrorism may hinder their expected result from tourism industries. When there is an unstable situation or warlike conflict in a country, people do not go out on holiday to that county; as a result, tourism naturally decreases.

Moreover, mass tourism that often relies on the allinclusive package tours does not benefit much to the local businesses and workers because of the leakage problem. Most of the earned money from these packages goes to the airlines and international companies (who have their headquarters in the tourists' countries) (UNEP). Thus, the amount of money remains in the community is very low. The local businessmen cannot develop their facilities as much as the tourists demand. The host country cannot supply the standards of equipment, food and other products that the travelers demand (Coastlearn). Eventually, the local businesses often face their income from mass tourism severely reduced by the creation of "all-inclusive" vacation packages. Receiving these offers the tourists stay on the same cruise ship or resort for their entire vacation, where they get everything they need and they make all their expenditures at the same venue. Consequently, there is 
not much opportunity left for the local people to gain from mass tourism due to this outflow of the money.

In addition, the multinational companies and large foreign businesses have a significant share in the import leakage. In the least developed host countries, especially in the poor developing destinations, they possess the necessary capital to invest in the construction of tourism infrastructure (UNEP). Consequently, export leakage arises when overseas investors who finance the resorts and hotels take their profits back to their home countries. Rich transnational corporations are involved in mass tourism, which may result in a lot of profits leaving the country (Gamesby). Mostly the jobs offered during mass tourism are seasonal. The employees find themselves out of work in the off seasons, which is frustrating and economically harmful for them and their families (Ibid). Land is lost from farming to infrastructure development for tourism purpose (Gamesby).

Besides, since lots of people visit and stay in the same place at the same time, it hampers the environmental elements such as land, water, air, flora and fauna of the destination (Johnpaul. E). In addition, it affects the manmade environment or built environment. The local people often do not benefit from the infrastructure development of the community (Johnpaul. E). Rather, this development increases the price of lands since it requires additional space to build hotel, accommodation and others (Ibid). During mass tourism, the demand of safe drinking water tremendously rises. The need for fresh water at present is much more than other times. It affects the whole host community. Sometimes the local women have to fetch water from far away due to scarcity of safe water in the surrounding areas (responsible travel). It has become difficult for the host country and community to tackle the situation. Besides, if the surrounding areas get flooded or devastated by natural disasters at this time, the situation undoubtedly worsens. A lot of tourists require a huge amount of food and water at the same time. It creates shortage of natural resources and makes tourism unsustainable (Gamesby).

Also, dive tourism has been creating physical damage to the coral reef systems. Divers topple and trample corals, and remove them for souvenirs. Dice boats carelessly drop and drag anchors on the reefs. This damage of coastal vegetation for aesthetic purposes results in the erosion of sand from beaches and reduces the areas suitable for turtle nesting (responsible travel). In some cases the front lightings of beaches confuse hatchlings; therefore, they cannot find their way to the water and safety. Corals and shells are also attractive part in the souvenir market. Ornamental corals are sold in many countries as cheap souvenirs (responsible travel). In addition, national and international tourists from various cultures introduce their values, norms and customs that may ruin the local culture and thus lead to cultural pollution (Gamesby).

\section{IMPORTANCE OF MONITORING MASS TOURISM}

The World Tourism Organization (WTO) states that "The Global Code of Ethics for Tourism sets a frame of reference for the responsible and sustainable development of world tourism, believing the code is necessary to help minimize the negative impacts of tourism on the environment and on cultural heritage while maximizing the benefits for residents of tourism destinations" (Miller, 2005). The Code of Ethics suggested by the WTO consists of the following 10 articles:

- Tourism's contributions to mutual understanding and respect between peoples and societies

- Tourism as a vehicle for individual and collective fulfillment

- Tourism, a factor for sustainable development

- Tourism, a user of the cultural heritage of mankind and a contributor to its enhancement

- Tourism, a beneficial activity for host countries and communities

- Obligations of stakeholders in Tourism Development

- Right to Tourism

- Liberty of tourism movements

- Rights of the workers and entrepreneurs in the tourism industry

- Implementation of the principles of the Global Code of Ethics for Tourism" (Miller, 2005)

Though the final article strongly recommends enforcing the code, there is no mention how the laws should be implemented. The WTO emphasizes on monitoring mass tourism, but it does not evidently provide any suggestions about how to manage the destructive impacts of mass tourism and receive the most benefits of it. The idea of sustainable tourism refers to preservation of the resources for future generations, the usage of tourism to contribute to environmental protection, lessening negative socio-economic impacts, and benefiting local people economically and socially (Pedersen). The WTO defines that Sustainable Tourism is "Tourism development that meets the needs of the present tourists and host regions while protecting and enhancing opportunity for the future" (Ibid).

Yet, no researcher or academic in Bangladesh depicts any clear picture of how to properly manage mass tourism in spite of having much negative impacts on the economy, community and environment of the country. On the other hand, there is high potential of mass tourism in Bangladesh especially during national holidays, winter seasons and other national, cultural and religious occasions. Therefore, it is the vital time to evaluate the effects of mass tourism on the country and take necessary initiatives to minimize the harmful consequences. Thus, the nation can properly utilize its natural resources and tourism industry for gaining most benefits of it. 


\section{How to maKe Mass Tourism MoRe Efficient AND SUSTAINABLE}

Below are some of the recommendations provided by the scholars and experts on mass tourism:

- 'Core zones' must be recognized and marked where human activity is prohibited altogether

- 'restricted zones' should be identified where only non-mechanized hard ecotourism is allowed

- 'high intensity zones' should be marked where services, accommodation and interpretation facilities are clustered to cater primarily for the soft 'ecotourism' market

- 'buffer zones' beyond the actual protected area where local communities undertake regulated, sustainable activities, needs to be identified " (Weaver).

Apart from taking the above steps, the government, and other tourism-concerned organizations can follow some strategies to decrease the miserable impacts of mass tourism. According to United Nations Educational, Scientific and Cultural Organization (UNESCO), the main responsibility for development of a country's tourism attractions depends on the government-funded tourism organizations such as National Tourism Offices (NTOs) (Pedersen). The NTOs should collaborate with hotels and air carriers to increase finance for destination promotion programs without harming the local communities (Ibid). It is true that the government or any other agencies cannot stop people from travelling at the same time neither it should discourage any national or international tourists from taking a trip at any of their preferable time. However, they can provide some alternatives for the local employees who lose their jobs right after the season is over. Also, nature and natural resources should be nurtured and monitored properly so that people cannot damage them. Tourists guide should check during the time of mass tourism, which may help prevent any activities that create cultural conflicts. Community people should be given enough return for their lands or other properties that they sacrifice for the development of tourism. They should not be given unfair share of the benefits. Thus, the government, private agencies, local communities as well as the whole nation can utilize the natural resources and get most benefits out of mass tourism while reducing the dangers of it.

\section{CONCLUSION}

The tourism sector of Bangladesh can contribute to achieving the country's vision for 2021 in many possible ways. However, mass tourism can harm economy, society, culture and environment of the country instead of benefiting them. In fact, in most cases the chance of negative impacts from mass tourism is much higher than the positive ones. Hence, the natural resources and tourism industry might not work as an asset of the country. Rather, it might become a burden for local community and the whole country. As a result, it requires proper monitoring, implementation of policies and accurate intervention of government, public as well as private sectors. The community people should be given fair profits, the national companies' needs to come forward so that the international ones cannot fill up the gaps, the environment should be protected and culture should be protected. Thus, the benefits from mass tourism will outweigh the costs. Therefore, properly managing and monitoring mass tourism in Bangladesh has become an inevitable task for the sustainable development of tourism industry.

\section{REFERENCES}

Biddulph, Robin. "Limits to Mass Tourism's Effects in Rural Peripheries." Annals of Tourism Research 50 (2015): 98-112. ScienceDirect. Elsevier. Web. 26 Aug. 2015. <http://www.sciencedirect.com/science/article/pii/S016 0738314001522>.

Dey, P., Uddin, S., \& Hasan, M. (2015). Tourists' Perception towards Cox's Bazar Sea Beach in Bangladesh as a Tourist Destination. Asian Business Review, 2(1), 54-60. doi: http://dx.doi.org/10.18034/abr.v2i1.316

Gamesby, Rob. "Mass Tourism." Coolgeography.co.uk. Coolgeography.co.uk. Web. 6 Aug. 2015. <http://www.coolgeography.co.uk/GCSE/AQA/Touris $\mathrm{m} /$ Mass Tourism/Mass Tourism.htm $>$.

Had Enough? Package of Shame. Responsible Travel. Responsible Travel. Web. 5 Aug. 2015. $<$ http:/ / www.responsibletravel.com/copy/had-enoughpackage-of-shame>.

Hani, F. (2016). Exploring Pull Factors of Travel Motivation: An Exploratory Study in Sylhet Region. Asian Business Review, 6(1), 15-20. doi: http://dx.doi.org/10.18034/abr.v6i1.778

Howlader, Ziaul Haque. "The Great Potential of Tourism." The Daily Star 17 Mar. 2013. The Daily Star. Web. 6 Sept. 2015. $<$ http://archive.thedailystar.net/beta2/news/the-greatpotential-of-tourism/>.

Howlader, Ziaul Haque. "Tourism Potentials in Bangladesh." The Brunei Times 26 Mar. 2012. The Brunei Times. Web. 17 Aug. $2015 . \quad<$ http://www.bt.com.bn/artculture/2012/03/26/tourism-potentials-bangladesh $>$.

Johnpaul.E, Ezeani. "IMPACT OF MASS TOURISM ON THE HOST DESTINATIONS." Enugu State Tourism Board. Enugu State Tourism Board, 2015. Web. 10 Aug. 2015. $<$ http://enugustatetourismboard.com/p.php?u=impactof-mass-tourism-on-the-host-desti\&id $=47>$.

Miller, Graham, and Louise Twining-Ward. "Sustainable Tourism." Monitoring for a Sustainable Tourism Transition: The Challenge of Developing and Using Indicators. CABI, 2005. 34. Web. 12 Aug. 2015 <https:/ / books.google.com.bd/books?id=xynGRx_fguoC \&pg=PA33\&lpg=PA33\&dq=importance + of + monitoring + $\underline{\text { mass+tourism }+ \text { for }+ \text { sustainable+development\&source }=\text { bl\& }}$ ots=PllgployQq\&sig=GbzUxthrcQNs3DjJQofVjApsNI4\&hl =en\&sa $=X \&$ redir esc $=y \# v=$ onepage $\& \mathrm{q}=$ importance $\% 20$ of \%20monitoring $\% 20$ mass $\% 20$ tourism $\% 20$ for $\% 20$ sustainable \%20development\&f=false $>$. 
Muzib, M., \& Banarjee, S. (2015). Tourism and Crime: The Case of Bangladesh. Asian Journal Of Humanity, Art And Literature, 2(3), 115-124.

Negative Economic Impacts of Tourism. United Nations Environment Program. UNEP. Web. 11 Aug. 2015. $<$ http://www.unep.org/resourceefficiency/Business/Sect oralActivities/Tourism/FactsandFiguresaboutTourism/I mpactsofTourism/EconomicImpactsofTourism/NegativeE conomicImpactsofTourism/tabid/78784/Default.aspx $>$.

Pedersen, Arthur. "Ma N Aging Tourism at World Heritage Sites: A Practical Manual for World Heritage Site Managers." World Heritage Manuals. UNESCO World Heritage Centre, 2002. Web. 22 Aug. 2015. $<$ http://whc.unesco.org/uploads/activities/documents/a ctivity-113-2.pdf $>$.

Rahman, Md. Lutfur, S.M. Nawshad Hossain, Sania Sifat Miti, and Dr. A K M Abul Kalam. "An Overview of Present Status and Future Prospects of the Tourism Sector in Bangladesh." Bangladesh Institute of Planners 3 (2010): 65-75. Bangladesh Institute of Planners. Web. 3 Aug. 2015. $<$ http://www.bip.org.bd/SharingFiles/journal_book/201 30722134114.pdf $>$.
Sustainable Tourism. Coastlearn. Coastlearn. Web. 13 Aug. 2015. $<$ http:/ / www.biodiversity.ru/coastlearn/tourismeng/why economicimpacts.html $>$.

The Effects Mass Tourism Has Had on Developing Countries. Responsible Travel Report. Web. 20 Aug. 2015.<http://www.responsibletravelreport.com/compone nt/content/article/2642-mass-tourism-effects>.

Tinne, W. (2015). Nation Branding: Beautiful Bangladesh. Asian Business Review, 2(1), 31-36. doi: http://dx.doi.org/10.18034/abr.v2i1.312

Tourism. Oxford Dictionaries. Oxford University Press, 2015. Web. 3 Aug. 2015. $<$ http://www.oxforddictionaries.com/definition/english/tourism $>$

Understanding Tourism: Basic Glossary. World Tourism Organization (UNWTO). UNWTO. Web. 7 Aug. 2015. $<$ http://media.unwto.org/en/content/understandingtourism-basic-glossary $>$.

Weaver, David, and Laura Lawton. "Sustainable Tourism: A Critical Analysis." CRC Tourism. CRC for Sustainable Tourism, 1999. Web. 16 Aug. 2015. <http://www.crctourism.com.au/wms/upload/resources /bookshop/SustainableTourism.pdf $>$. 